\title{
RESEARCH, POLITICS AND THE ANTIBUSING DEBATE
}

\author{
Gary Orfield*
}

\section{INTRODUCTION}

A generation of national struggle over school desegregation policy has shown that the only thing that is worse for social science than being ignored altogether is being taken too seriously too soon. The original Brown case went to the Supreme Court accompanied by a brief by dozens of prominent social scientists affirming the damaging character of segregation. The South presented its own social science evidence against desegregation. ${ }^{1}$ Although the Supreme Court made only passing reference to social science in its 1954 decision $^{2}$ and none at all in the school decisions that followed, social scientists claimed major credit for the victory, and Southern opponents based much of their criticism on the claim that the Court had abandoned its proper role by considering speculative academic social science research in place of law.

The controversy only deepened in the 1970s when some social scientists began to attack the urban school desegregation orders of the federal courts. Articles claiming that the unpopular busing policy produced no academic gains for black children ${ }^{3}$ and accelerated white abandonment of city public schools ${ }^{4}$ received extraordinary national attention from the press and policymakers. Judges were confronted with social scientists testifying for diametrically opposed policies, and bitterness among some leading researchers became notorious. ${ }^{5}$ Some school districts even funded large-scale social science research to prove that desegregation should not be implemented. ${ }^{6}$ School districts and civil rights advocates have each developed a coterie of social scientists who regularly appear as witnesses and consultants in school desegregation litigation.

* Associate Professor. Political Science Dept.. University of Illinois. After this article was drafted, the author had the opportunity to try out some of the ideas proposed here while serving as chairman of the Illinois Office of Education's Technical Assistance Committee on the Chicago Desegregation Plan and as a court-appointed expert in the Los Angeles school desegregation case.

1. Argument 60-61 (L. Friedman ed. 1969).

2. Brown v. Board of Educ., 347 U.S. 483, 494 at n.11 (1954).

3. See, e.g., Armor, The Evidence on Busing, 28 Pub. Interest 90 (1972).

4. See, e.g., J. Coleman, S. Kelly \& J. Moore, Trends in School Integration, 1968-73 (Aug. 1978) (Urban Institute Paper No. 722-03-01) [hereinafter cited as J. Coleman].

5. See Pettigrew, Useem, Normand \& Smith, Busing: A Review of "The Evidence," 30 PuB. Interest 88 (1973); Armor, The Double Double Standard: a Reply, 30 Pub. InTerest 119 (1973).

6. See the discussion of the Los Angeles and St. Louis studies, infra. 
This public attention has been a new experience for social scientists who have traditionally received little notoriety compared to celebrities in science economics, law, and other professions. Authors of relatively modest articles on school busing have sometimes found themselves at the center of a national media barrage and deluged with invitations to make cosmic statements on the future of cities they have never visited.

The attention, however, has served to highlight and even intensify internal divisions within the scholarly community, both on methodology and analytic assumptions. Moreover, a series of emotional disagreements has surfaced about the role scholars should play in public disputes about the future of American race relations. These problems have been magnified by mass media coverage, which has often selectively and inaccurately reported the scholarly disputes, and hopelessly muddled the difference between the empirical findings of a given scholar and the political judgments he may reach as a citizen. Of course, scholars themselves sometimes blur this distinction.

The involvement of scholars in school desegregation cases has created deep fissures within the universities, and between the academic world and civil rights leaders, public officials, and antibusing groups. Although most school desegregation research is motivated by a desire to contribute to a better understanding of racial problems and wise public policy, the transmission of research findings has proved to be a difficult and even perilous process. The effort has real costs, and there are serious questions about whether there have been any compensating gains.

The fact remains that there is no satisfactory alternative to using the best available social science data in developing remedies for segregation. Although the social sciences may not always be relevant in determining whether city school officials have violated constitutional requirements, they provide important insights into the kind of school desegregation plan that is likely to work best, which legal analysis alone cannot do. Although social science may not always have the final answers on many issues, in a number of cases the research findings are sufficiently clear and consistent to show that a particular approach is more likely to work than another. The alternative to using social science data and findings is to rely on the hunches and common sense of judges and lawyers about very complex issues of urban demography, educational policy, and other fields in which they usually have no professional training and little knowledge of what has happened in other cities across the nation.

There are a number of obstacles, however, to the effective use of social science research. This article examines several aspects of the problem:

1. the selective perceptions of the research by the media and policymakers; 
2. the way social science concepts reshape the character of the desegregation debate;

3. the deepening distrust of social scientists by civil rights leaders;

4. the contradictions between some research findings and the notions about social reality embodied in current desegregation plans.

After examining these obstacles and problems, the article concludes with a discussion of the needs of judges, administrators, and elected officials who must make decisions and devise plans regardless of the academic conflicts and confusions that persist in some areas of desegregation research.

I

Selective Perceptions of the Research: The Role of the Media

Most social science research is simply irrelevant to decisionmakers because they do not know it exists. Generally, research appears only in obscure scholarly journals or in mimeographed reports to federal agencies or private foundations. Under such circumstances, the only possible impact is indirect: the research can influence the work of other scholars in the field and of technically-skilled journalists. Eventually it may be incorporated in more widely read works.

A social science study may become highly visible either because of the political clout of its sponsor or because of the apparently novel or newsworthy character of its principal findings. Occasionally the reputation of the investigator may also be responsible for its receiving public attention. Some of the most influential research studies have been sponsored by government agencies and a handful of the largest foundations, which actively have used the results to promote particular policies.

The federal government has sponsored only one large-scale study of school desegregation, the 1966 report Equality of Educational Opportunity (the Coleman Report). ${ }^{7}$ This study, produced by a team of academic researchers working closely with the United States Office of Education, has helped to shape both the research agenda and the debate over desegregation policy. Innumerable studies have reanalyzed and reinterpreted the Coleman data. The U.S. Commission on Civil Rights drew heavily on the data for its influential 1967 report, Racial Isolation in the Public Schools. ${ }^{8}$

Though the Coleman Report initially received little media attention, it had a profound effect on academic thinking about desegregation. By the late 1960s, its basic conclusions were broadly accepted by experts and had begun to in-

7. Equality of Educational Opportunity (1966) [hereinafter cited as the Coleman RePORT].

8. 2 U.S. Comm'n on Civil Rights, Racial Isolation in the Public Schools (1967). 
fluence policy. Although some critics pointed to significant methodological problems in the report, ${ }^{9}$ it was such an advance over previous research that these questions were not seriously examined for some time.

The major policy conclusions of the Coleman Report were:

1. School desegregation produces an educational gain for black children not because of contact with whites but because it is an indirect way to put many poor children from families with weak educational backgrounds in classes where the pace and the expectations are set by a majority of children from more privileged backgrounds;

2. The positive impact is relatively small in any case, still leaving a substantial achievement gap between white and minority children;

3. Schools are more important for poor children, while the home background is more decisive for white middle-class children; desegregation has no impact on the achievement of white middleclass children;

4. Compensatory education is probably a futile strategy, since the level of spending on schools is not significantly related to the achievement of children.

The Coleman Report had surprisingly little influence on school desegregation litigation. Although Hobson v. Hansen,$^{10}$ one of the first urban school desegregation decisions, drew on the report, the precedent-setting urban school desegregation cases were based on more traditional legal reasoning. The Supreme Court's rulings on citywide desegregation in the mid-seventies made no reference to sociological data. ${ }^{11}$ The research findings of the Coleman Report, however, provided a rationale for the arguments of desegregation supporters opposing the wave of angry political criticism triggered by the systemwide busing plans approved by the Supreme Court. When Congress first considered legislation restraining the courts, for example, Professor Coleman was an

9. See, e.g., Bowles \& Levin, The Deteminants of Scholastic Achievement-An Appraisal of Some Recent Evidence, $3 \mathrm{~J}$. of Human Resources 3 (1968).

10. Hobson v. Hansen, 269 F. Supp. 401 (D.D.C. I967), aff'd sub nom., Smuch v. Hobson, 408 F.2d 175 (D.C. Cir. 1969).

11. See Keyes v. School Dist. No. 1, 413 U.S. 189 (1973); Swann v. Charlotte-Mecklenburg Bd. of Educ., 402 U.S. 1 (1971).

Ironically, the Coleman Report may have had more impact on legal challenges to inequitable school finance systems than to segregated school systems. In its 1973 decision upholding the constitutionality of the system by which Texas distributed school funds, the Supreme Court cited C. Jencks, J. Coleman, E. Campbell, C. Hobson, J. McPartland, A. Mood, F. Weinfeld \& R. YORK, INEQUALITY (1972), one of the most widely publicized interpretations of the Coleman data, in support of its decision that federal courts should not interfere in state school financing schemes. San Antonio Independent School Dist. v. Rodriguez, 411 U.S. 1, 43 n.86 (1973). 
important spokesman against the drastic restrictions being considered. ${ }^{12}$ Other scholars testifying before the widely publicized Mondale Committee desegregation hearings also cited the Coleman Report. ${ }^{13}$ The U.S. Commission on Civil Rights' Racial Isolation in the Public Schools ${ }^{14}$ report was widely circulated among minority groups and educators. Although the Coleman Report provided desegregation supporters with some useful ammunition, its major premise-that class rather than race was the key factor-never penetrated the public discussion.

The second study to become nationally visible was of a very different character and had a decidedly negative impact on urban school desegregation efforts. David Armor's article, "The Evidence on Busing," which was published in mid-1972, instantly made the young Harvard researcher one of the most publicized academics in the nation. ${ }^{15}$ In his article, Armor claimed that the Supreme Court had favored integration initially because of the belief that it would improve the education of black children. ${ }^{16}$ Armor, however, concluded on the basis of his analysis of several projects undertaken by other researchers, and the results obtained in his own study of a small, voluntary plan in effect in metropolitan Boston, that the Court was wrong. Busing plans, he said, were ineffective or even counterproductive, regardless of whether the objective was to improve the achievement levels of blacks, the educational or occupational aspiration levels of blacks, or relations between the races.

Coming in the midst of an election-year struggle over antibusing legislation, at a time when the courts were considering plans for busing between central cities and their suburbs, ${ }^{17}$ this recantation by a Harvard professor who had once worked for the U.S. Commission on Civil Rights received spectacular media coverage. Public Interest, the journal which published the article took the unusual step of holding a prepublication press conference, resulting in the article receiving headline coverage in the Washington Post and other major newspapers. Within days, the article was cited on the floor of Congress, in editorials, and in political speeches as scientific evidence that busing was a

12. E.g., Equal Educational Opportunity, Pt. 1A: Hearings Before Senate Select Comm. on Equal Educational Opportunity, 91 st Cong., 2d Sess. 87-134 (April 21, 1970).

13. Hearings and reports of the Mondale Committee (The Senate Select Comm. on Equal Educational Opportunity) during the $1970-72$ period contain numerous references to the Coleman Report.

14. 2 U.S. Comm'n on Civil. Rights, supra note 8.

15. Armor, supra note 3 .

16. Id. at 91 .

17. See, e.g., Bradley v. School Board, 338 F. Supp. 67 (E.D. Va.), rev'd, 462 F.2d 1058 (4th Cir. 1972), aff'd by an equally divided Court, 412 U.S. 92 (1973) (the Richmond case); Bradley v. Milliken, (E.D. Mich. Mar, 28, 1972) (unreported findings of fact and conclusions of law), modified, 345 F. Supp. 914, aff'd, 484 F.2d 215 (6th Cir. 1973), rev'd and remanded, 418 U.S. 717 (1974) (the Detroit case). 
worthless concept. Armor himself became an important witness at congressional hearings and in a number of school cases. ${ }^{18}$ School districts sought, unsuccessfully, to use his testimony to convince judges not to order busing. ${ }^{19}$

Armor's greatest impact was not on the academic world but on policymakers and the mass media. Although his conclusions were hotly disputed by other researchers, they entered the national repository of accepted wisdom. Even those who did not know Armor's name and had never read his article often cited its basic conclusion as if it were a scientific fact-something that "research has shown." Rep. Podell (D-N.Y.), for instance, saw it as a reason to support President Nixon's antibusing bill: "There is no satisfactory evidence that busing aids the educational process. Most recent educational research shows that in many cases busing hurts educational progress."20 Another Northern Democrat, Rep. Veysey of Ohio, cited "reliable research studies like the Armor report" as proof of busing's "adverse effect on the education children receive." 21

The concern was not limited to Congress but was shared by the public at large. Media coverage indicating that there was scientific proof of educational damage may well have reinforced and heightened concern among parents. For example, a national survey conducted during the 1972 election period showed that 27 percent of the public believed that test scores of white children had "fallen sharply in desegregated schools." Only about one-third of the public recognized that this claim was false. ${ }^{22}$ Even the leading social science critics of busing had made no such charge-Armor, for example, had found no adverse impact on white students from desegregation. ${ }^{23}$

Scholarly rebuttals of Armor's analysis received far less attention from the media and policymakers. While there was significant coverage of the bitterness and backbiting within the Harvard faculty over the issue, the response by Thomas Pettigrew and several other scholars ${ }^{24}$ received far less substantive media coverage and almost no attention in Congress. The timing of Armor's article and its congruence with an emerging white consensus against busing gave his brief and controversial treatment of the data a powerful and lasting impact.

18. For example, Armor was the principal social science witness in support of President Nixon's antibusing legislation in 1972. Equal Educational Opportunities Act of 1972: Hearings before Senate Comm. on Labor and Public Welfare, Subcomm. on Education, 92d Cong., 2d Sess. $1194-204$ (Sept. 25, 1972) [hereinafter cited as Armor testimony].

19. See, e.g., Northcross v. Board of Educ., 466 F.2d 890, 894 \& n.4 (6th Cir. 1972).

20. 118 Cong. Rec. 28864 (1972).

21. Id.

22. U.S. Comm. on Civil Rights, Public Knowledge and Busing Opposition (March 11, 1973)

(processed) (based on a survey conducted by Opinion Research Corporation).

23. Armor lestimony, supra note 18, at 1196.

24. Pettigrew, Useem, Normand, \& Smith, supra note 5. 
School desegregation research again made headlines in early 1975 when Professor James Coleman delivered a paper at the annual meeting of the American Educational Research Association on some preliminary results of an analysis of the causes of "white flight." Coleman and his colleagues found a statistical relationship between the implementation of school desegregation plans and the rate of decline in white enrollment in the twenty-two largest central city school districts. ${ }^{25}$ This paper, a highly tentative interpretation, which included a number of speculative conclusions unrelated to the research, began to influence national policy even before it was published later that year. The impact of the paper increased when Coleman gave a series of wideranging interviews, which were carried in major newspapers and on television. ${ }^{26}$ Because of his academic stature and his previous notoriety from the Coleman Report, Coleman's comments and speculations were treated as if they were proven research findings. Although Coleman soon found himself involved in an angry scholarly debate over his research methods and policy conclusions, ${ }^{27}$ he began to file depositions in pending court cases, including the Boston and Louisville cases, urging restraint on busing to avoid massive white flight. ${ }^{28}$ More importantly, Coleman's views were widely accepted by members of Congress, including those who had once been supporters of school desegregation, ${ }^{29}$ and newspapers across the country saw the study as the rejection of busing by one of its most important academic exponents.

A thorough examination of the treatment of the Coleman study by the most widely-read newspapers and weekly news magazines documented the highly selective media perception of the scholarly dispute. ${ }^{30}$ The average publication carried three and one-half stories on the white flight issue as interpreted by Coleman. Although most other scholars who spoke out on the issue disagreed with either Coleman's methodology or his policy conclusions, ${ }^{31}$ and Coleman himself made major modifications in successive drafts of his paper, 85 percent of the news space devoted to the question uncritically reported Coleman's initial assertions. More than two-fifths of the publications never

\footnotetext{
25. J. Coleman, supra note 4 , at 39 .

26. See, e.g., Busing Backfired, Nat'l Observer, June 7, 1975, at 1, col. 1 .

27. See,e.g., Symposium on School Desegregation and White Flight (1975) (Sponsored by the Notre Dame Center for Civil Rights and the Center for National Policy Review).

28. See, e.g., Morgan v. Kerrigan, 530 F.2d 401, 420 n.29 (lst Cir. 1976).

29. Senators Joseph Biden (D-Del.) and Thomas Eagleton (D-Mo.), for example, repeatedly cited the white flight argument to justify their 1977 antibusing legislation. See, e.g., S. 1132, 95th Cong., 1st Sess. (1977). See also Eagleton on Busing, St. Louis Post-Dispatch, July 24, 1977, § B, at 2 , col. 4 .

30. R. Weigel \& J. Pappas, Social Science and the Media: Press Coverage of the "White Flight" Controversy, at 8-10 (1977) (unpublished). See also Taylor, Benjes, \& Wright, School Desegregation and White Flight: The Role of the Courts, in Symposium on School Desegregation and White FLiGHT, supra note 27, at 69.

31. Professors Weigel and Pappas examined 20 leading publications over a six-month period in 1975 .
} 
carried a story critical of the Coleman study, and only about one-eighth of the articles reported any of the specific questions raised about Coleman's research. ${ }^{32}$ It is not surprising that Coleman's findings entered public debate as a proven fact rather than as a tentative hypothesis.

Media treatment of new pronouncements by Coleman and Armor in 1978 continued the old pattern. An article by Coleman, based on a speech he had given five months earlier ${ }^{33}$ and containing neither new research nor new opinions, was published by the Chicago Tribune. ${ }^{34}$ It immediately became the focus of widespread press coverage ${ }^{35}$ and was cited as "new" evidence by editorials questioning extensive school desegregation plans. ${ }^{36}$ The Washington Post's story on Coleman's views ${ }^{\mathbf{3 7}}$ was repeatedly cited in a Senate debate on an antibusing issue to indicate that Coleman had new research findings that supported the antibusing position. ${ }^{38}$

The publicity given to an unpublished study on white flight by David Armor was even more remarkable. A draft article on white flight Armor had prepared for delivery at a sociological meeting received major coverage in the Los Angeles Times, ${ }^{\mathbf{3 9}}$ in many other papers through the Associated Press wire service, on the front page of the Washington Post, ${ }^{40}$ and in a full-page story

32. R. Weigel \& J. Pappas, supra note 30, at 8-10.

33. The speech was given in April at Henry Ford Community College in Dearborn, Michigan and was basically a statement of Coleman's personal views on the value of integration, primarily in improving the achievement of black children.

34. James S. Coleman, Can We Integrate Our Public Schools Without Busing? Chi. Tribune, Sept $17,1978, \$ 2$ (Perspective/Business), at $1,5$.

35. See, e.g., Lawrence Feinberg, Integration Benefits Discounted, Washington Post, Sept. 18, 1978, $\S \mathrm{A}$, at 1, 5. The Coleman article was reprinted in the Chicago Sun-Times a little over a week after it had appeared in the Tribune. James S. Coleman, False Beliefs About School Integration, Chi. Sun-Times, Sept. 26, 1978, at 39.

36. Chi. Sun-Times, New Look at Integration, Sept. 26, 1978, at 41; The Buses Roll, Wall St. J., Oct. 4,1978 , at 18 .

37. Note 35 supra. Twenty-four members of the National Review Panel for School Desegregation Research protested inaccuracies in the news coverage and the failure to report other research findings. See National Review Panel for Desegregation Research, Press Release, Desegregation Has Worked, Expert Panel Says (September 29, 1978). In response, the Chicago Tribune published an article by Robert Crain and Rita Mahard, summarizing their recent research on the academic effects of school desegregation. Robert L. Crain and Rita E. Mahard, How Integration Can Help Black Students Achieve, Chi. Tribune, Oct. 8, 1978, $\$ 2$ (Perspective/Business) at 1 . See Crain \& Mahard, Desegregation and Black Achievement: A Review of the Research, 42 LAw \& Contemp. ProB., Summer 1978, at 17 .

The Washington Post initially responded to the protest by running two paragraphs on an inside page at the conclusion of a story about the extent to which blacks are attaining positions on college faculties. Auerbach, Black College Staff Parity Seen Taking at Least 45 Years, Wash. Post, Sept. 29, 1978, $\$ \mathrm{~A}$, at 7 . Only after repeated requests did it run a response to the Coleman coverage on its Op-Ed page on October 14, 1978. Willis D. Hawley and Betsy Levin, "Wayward" Coverage of School Desegregation, Wash. Post, Oct. 14, 1978, § A, at 17.

38. 124 Cong. Rec. S16300-16302 (daily ed. Sept. 27, 1978).

39. Oliver, Forced Busing Spurs Racial Isolation, Special from Los Angeles Times, in Chicago SunTimes, August 23, 1978.

40. Feinberg, Prince George's "White Flight" Seen Linked to Busing Order, Wash. Post, Sept. 25, $1978,8 \mathrm{~A}$, at 1,7 . 
in Time magazine. ${ }^{41}$ The Time coverage was highly favorable, ${ }^{42}$ criticizing academics who had "kept busy stomping all over Coleman's findings" on white flight. This new report by a "Harvard-trained" sociologist, the magazine announced, had produced "remarkably consistent" findings. Each of the articles contained at least passing reference to some of the serious criticisms of Armor's work. ${ }^{43}$ Nonetheless, the coverage was massive and wholly out of proportion with that given to other published and unpublished studies of the subject. Selective perception was again in operation.

It would be overstating the case, of course, to claim that these few prominently discussed studies changed national policy. On the contrary, they may have become so prominent because they reflected, and provided a rationale for, a change in national policy that was already underway. To the extent that university researchers are thought to be dispassionate scientists who are generally committed to objective truth, this selective perception of universityrelated research findings may have helped to legitimize and camouflage a general social and political movement away from the integrationist policies of the sixties.

In view of the controversy surrounding desegregation policies and the extraordinary public attention given to some of the extant research studies, it is puzzling that the 1966 Coleman Report remains the only national assessment of the effect of desegregation. Experts in the field, including Coleman himself, have long conceded that the 1966 study was limited to a narrow range of issues, hastily studied during a period before any major city had desegregated. ${ }^{44}$ Although the need for more sophisticated information concerning the desegregation process over time has been apparent for years, there has been no major federal or private effort to find out what is actually happening in desegregated schools.

Neither side in the national debate over urban school desegregation has pressed for basic research on this issue. One reason may be that both sides are so certain of the correctness of their positions that proof seems unnecessary or even irrelevant. Although both the Nixon and Ford Administrations consis-

41. Forced Busing and White Flight, Time, September 25, 1978, at 78.

42. Id. The Time report even adopted the "forced busing" rhetoric of desegregation opponents:

"[T]here is now considerable academic consensus that in large cities a significant linkage exists between white flight and forced busing. The fact that sociologists show signs of catching up with everybody else's common-sense observation should be reassuring."

During this same period a number of articles and reports on white flight by prominent scholars including Reynolds Farley, Christine Rossell and others received very little national press attention. See, e.g., C. Rossell, Assessing the Unintended Impacts of Public Policy: School Desegregation and Resegregation (1978) (report prepared for the National Institute of Education); Rossell, School Desegregation and Community Social Change, 42 Law \& Contemp. Prob., Summer 1978, at 133.

43. The Time article noted that Armor's treatment of demographic factors and his theory of anticipatory white flight had been critized. Supra note 41.

44. See, e.g., ON Equity of Educational. Opportunity (F. Mosteller \& D.P. Moynihan eds. 1972). 
tently asserted that busing was damaging to education, ${ }^{45}$ and congressional debates were filled with similar claims, ${ }^{46}$ leading opponents of school desegregation have never called for a major research effort. In addition, when the principal governmental proponent of urban school desegregation, the U.S. Commission on Civil Rights, did launch a research enterprise, the project was jettisoned before any data could be collected. The development of a comprehensive multi-year research strategy was funded by the Commission, but after the report was released, ${ }^{47}$ it was quietly shelved, in part because many minority leaders had concluded that social scientists were hostile to desegregation. ${ }^{48}$

More limited, but nonetheless significant, federal evaluations also have been largely ignored, though they contain positive findings about the effects of desegregation, a much more complex view of the changes that occur within schools that undergo desegregation, and important ideas about improving the desegregation process. A series of reports by the National Opinion Research Center, the Educational Testing Service, and the Systems Development Corporation analyzed changes over a period of years in a number of individual classrooms and schools that have been desegregated. The findings of these exploratory studies all point toward broadly similar requirements for successful desegregation: effective leadership by the principal, staff training programs, rules that students see as fair, and explicit efforts to teach students about historical and contemporary American racial and ethnic relationships. ${ }^{49}$ Though these studies were substantial research undertakings and produced significant findings, most were never discussed by the media and never entered the policy debate. Many of those undertaken for HEW were not even published.

Even a very brief review of a decade of scholarly investigations of the effects of school desegregation demonstrates that there is little relationship between the merit of a study and its visibility and influence on policy. Policymakers share the normal human tendency to heed research findings

45. Statement About Desegregation of Elementary and Secondary Schools, 1970 Pub. PAPERS 304,307 .

46. Notes 20-21 supra \& accompanying text.

47. R. Crain, D. Armor, F. Christen, N. King, M. Mclaughlin, G. Sumner, M. Thomas, \& J. Vanecko, Design for a National longitudinal Study of School Desegregation (Rand No. 1516, Sept. 1974).

48. See pp. [14-15] infra.

49. 1-2 National Opinion Research Center, Southern Schools: An Evaluation of the Emergency School Assistance Program and of School Desegregation (1973); G. Forehand, M. Ragosta, \& D. Rock, Conditions and Processes of Effective School Desegregation (1976) (Final Report of research undertaken by contract with the Dept. of Health, Educ., \& Welfare); System Development Corp., The Third Year of Emergency School Aid Act (ESAA) Implementation (1977) (Report of Research undertaken by contract with the Office of Education). See also Orfield, How to Make Desegregation Work: The Adaptation of Schools to their Newly-Integrated Student Bodies, 39 Law \& Contemp. Prob., Spring 1975, at 314. 
that agree with their perceptions. With the exception of a few specialized journalists, the press continues to cover researchers "not for saying what is true but for saying what is startling."50

II

Transformation of the Desegregation Debate:

Research as a Source of New Paradigms

Though research on school desegregation is still at a relatively primitive stage, social science concepts from the academic community have helped transform the way we speak about and view the desegregation process. In Brown $v$. Board of Education, ${ }^{51}$ the Supreme Court devoted only one footnote to social science research. ${ }^{52}$ Its decision spoke not of test scores but of the damage to the "hearts and minds" of black children forced to attend segregated schools. ${ }^{53}$ And since 1954, the school desegregation decisions have not referred to social science research. ${ }^{54}$ The task, as the Court has seen it, is to eliminate the evil of officially imposed segregation of black and Hispanic children. The appropriate remedy for this constitutional violation is desegregation. ${ }^{55}$

Confronted with the problem of measuring whether desegregation "worked," social scientists began to reshape the issue, often without any conscious intent. School districts and governmental agencies naturally turned to educational researchers for immediate answers and educational researchers naturally took up their most frequently used instruments, standardized achievement tests. Though such tests were themselves highly controversial, the technology of testing was highly developed, familiar, and easy to use. These tests were usually administered in the fall and the spring of a single school year, often the first and most difficult year of an unplanned transition to desegregation.

The choice of achievement test measures set a standard for success and for "failure" of desegregation. It rested on an assumption not found in the Brown case-that desegregation could only be justified on the basis of strong educational gains that presumably would arise merely by placing minority and white children in the same classroom. Armor took this one step further, by establishing his own standard-the elimination of the entire yearly increase in

50. Crain, Why Academic Research Fails To Be Useful, 84 ScH. Rev. 337 (1976).

51. 347 U.S. 483 (1954).

52. Id. at 494, n. 11 .

53. Id. at 494 .

54. See, e.g., Keyes v. School Dist. No. 1, 413 U.S. 189 (1973); Swann v. Charlotte-Mecklenburg Bd. of Educ., 402 U.S. 1 (1971).

55. But see Yudof, School Desegregation: Legal Realism, Reasoned Elaboration, and Social Science Research in the Supreme Court, 42 Law \& Contemp. Prob., Autumn 1978, at 57, arguing that, in the more recent cases, the Court, or at least some of its members, has adopted the position that "nondiscrimination" rather than integration through busing of pupils is the appropriate remedy. 
the gap between average white and black achievement scores. ${ }^{56}$ Where this standard-a standard that no educational reform had achieved-was not attained, desegregation was deemed a failure. Use of this unrealistically high standard led to the conclusion that busing-indeed, desegregation in general-had failed. The Supreme Court, Armor determined, had been wrong.

The white flight research has once again transformed the way the school desegregation issue is viewed. Now neither desegregation itself nor test score gains are sufficient to support a systemwide plan. If the rate of white suburbanization increases during the transition year-that is, the first year in which the desegregation plan is implemented-desegregation is often described as a failure. The initial problem of racial segregation, viewed from the perspective of minority children, has been reformulated as a problem of urban neighborhood stability, viewed from the perspective of the central city white. The policy recommendation Coleman derived from his white flight $s^{2} \mathrm{dy}^{57}$ calls for very limited or voluntary desegregation. Although the federal government had once been hailed by Northern intellectuals for forcing desegregation in Little Rock in 1958 in spite of local resistance, ${ }^{58}$ the new mode of analysis made local resistance a justification for inaction. For example, in pending cases in St. Louis, ${ }^{59}$ Los Angeles, ${ }^{60}$ San Diego, ${ }^{61}$ and elsewhere school districts placed heavy emphasis on specially commissioned social science research and testimony concerning white flight to support their contention that desegregation should be strictly limited. ${ }^{62}$

56. Studies have shown that while the average minority pupil scores lower than the average white pupil on achievement tests at every grade level, the gap between the two groups increases rather than decreases with more years of schooling. For example, blacks in the metropolitan Northeast are 1.6 years behind whites in the same region at 6 th grade, 2.4 years behind at 9th grade, and 3.3 years behind at 12 th grade. Coleman REPORT, supra note 7 , at 21 .

57. J. Coleman, supra note 4.

58. Cooper v. Aaron, 358 U.S. 1 (1958).

59. A special survey was commissioned by the Board of Education of St. Louis. One unusual feature of the survey was that the pollsters were provided with copies of a letter from the mayor urging citizens to cooperate as part of the survey. The study was conducted by the St. Louis Research Group, Inc. Population and Desegregation: City of St. Louis (September 23, 1977) (unpublished report).

60. The Los Angeles telephone survey of possible white flight was directed by David Armor and conducted by Marylander Marketing Research. See Marylander Marketing Research, note 171 infra. In Crawford $v$. Board of Education, the results, accompanied by declarations by several social scientists, were offered as evidence. See, e.g., Continued Deposition of David J. Armor, Crawford v. Board of Educ., No. C 822854 (Los Angeles County Super. Ct., June 6, 1977).

61. David Armor conducted research and testified for the school board in the San Diego case on the white flight issue. His research is cited in Armor, White Flight, Demographic Transition, and the Future of School Desegregation (Aug. 1978) (paper presented at the American Sociological Association Meetings, San Francisco, California).

62. Although the question whether courts should consider the phenomenon of "white flight" in shaping a desegregation remedy has surfaced in several lower court cases, the Supreme Court has not yet directly confronted the issue. See discussion in Levin \& Moise, School Desegregation Litigation in the Seventies and the Use of Social Science Evidence: An Annotated Guide, 39 LAw \& ConтемP. Prob., Winter 1975, at 50, 93-98. 
As the language of the research community has come to displace the language of the court decisions, we have begun to talk about desegregation in a strange way: discussion centers on demographic change rates, test score standard deviations, and indices of self-concept. Rarely is desegregation discussed as an important end in itself or even as the appropriate remedy for the deliberate violation of constitutional rights.

III

Social Scientists as the Enemy:

\section{The Perspective of Civil Rights Leaders}

From World War II until the mid-sixties, civil rights leaders believed they had important allies in the universities who provided both intellectual support for the movement and volunteers for direct action. No leading scholar attacked the goal of integration. During the early seventies, however, civil rights groups discovered that the involvement of social scientists in both the judicial and legislative process was a double-edged sword that seemed to cut more powerfully against desegregation than it ever had against segregation. The research findings of Professors Armor and Coleman were cited in support of efforts to resist desegregation. Daniel P. Moynihan's Labor Department study, The Negro Family, seemed to blame the problems of society on the weakness of the black family. ${ }^{63}$ Even the old issue of genetic inferiority was reawakened in the widely-discussed writings of Arthur Jensen.$^{64}$ Civil rights leaders who had been disappointed by the backlash against affirmative action on campus feared a revival of turn-of-the-century "scientific racism." ${ }_{55}$

The crisis produced searing attacks on individual social scientists by prominent civil rights leaders and a deepening distrust of the entire research enterprise. Coleman's white flight paper, ${ }^{66}$ for example, generated repeated denunciations by the NAACP and such leading black scholars as Kenneth B. Clark and Robert Green. ${ }^{67}$ Constitutional rights, they insisted, must not depend upon the particular approach to the use of the regression equations in fashion in any given year or the current racial mood in academe. A basic mistrust grew.

63. U.S. Labor Dep't, The Negro Family: The Case for National action (1967). For a critique of this study, see L. Rainwater \& W.L. Yancey, The Moynihan Report and the PoliTiCs of Controversy (1967).

64. Jensen, How Much Can We Boost IQ and Scholastic Achievement?, 39 Harv. Educ. Rev. I (1969).

65. The development of theories of black inferiority by leading social theorists helped to justify the disenfranchisement of Southern blacks and the ending of Reconstruction era civil rights protections in the late nineteenth and early twentieth centuries. See generally The Development of Segregationist Thought (I. Newby ed. 1968).

66. J. Coleman, supra note 4.

67. N.Y. Times, June 25, 1975, at 49, col. 1; id., July 3, 1975, at 23, col. 1; Wash. Post, July 1, $1975, \S \mathrm{C}$, at 1 , col. 6 . 
As long as the decisions of the federal courts continued to require substantial desegregation in urban school districts, the strategy of civil rights groups was to treat research as irrelevant while denouncing researchers who recommended less integration. In the 1974-77 period, however, when the Supreme Court moved to severely constrain the possibility of effective and lasting desegregation in many urban centers, the strategy became less viable. The Supreme Court's decisions in the Detroit, ${ }^{68}$ Pasadena, $^{69}$ and Dayton ${ }^{70}$ cases showed that the Court had begun to accept a number of propositions about the nature of urban racial change that precluded significant desegregation in many cities. Research on these propositions has thus become a matter of urgency if civil rights lawyers are to avoid erosion of existing legal principles. At a time when their opponents are actively using and even financing research that supports their position against desegregation, continued opposition to social science research among integrationists leaves the field to the critics.

\section{IV}

The Relationship Between Research and Policymakers' Assumptions About Society and Racial Change

\section{A. The Role of Politics}

Since 1972, the political intensity of the busing issue has declined and few new plans have been implemented, yet the assumptions of researchers critical of busing have become more widely accepted. Busing was not a major issue in the 1976 election. Yet even though the external pressures had eased, support for desegregation efforts continued to shrink.

The political character of the issue changed because desegregation had become routine in much of the South and relatively little was undertaken in the North. The 1972 election took place in the midst of the South's first year of large-scale busing, ${ }^{71}$ also a period when lower federal courts were ordering metropolitan desegregation. ${ }^{72}$ Four years later the antibusing groups had disbanded in most of the South, and public attention had turned to new issues. By 1975, the Supreme Court had ruled against metropolitan desegregation except in very special circumstances. ${ }^{73}$ Only one

68. Milliken v. Bradley, 418 U.S. 717 (1974).

69. Pasadena City Bd. of Educ. v. Spangler, 423 U.S. 1335 (1975).

70. Dayton Bd. of Educ. v. Brinkman, 433 U.S. 406 (1977).

71. There were far more urban desegregation orders in 1971 and 1972 than in any year since because it was then a relatively simple matter for civil rights lawyers to file motions to update existing desegregation orders in the South to meet the new Supreme Court standards articulated in Swann v. Charlotte-Mecklenburg Bd. of Educ., 402 U.S. 1 (1971).

72. Note 17 supra.

73. See Evans v. Buchanan, 423 U.S. 963 (1975) (summary affirmance); Milliken v. Bradley, 418 U.S. 717 (1974). 
or two Northern cities were desegregating each year. ${ }^{74}$

Each federal court order seemed to stimulate a new round of antibusing legislation in Congress. The Detroit litigation ${ }^{75}$ led to the proposal of amendments by several Michigan Congressmen and Senator Robert Giffin (RMich.), ${ }^{76}$ and the Boston litigation ${ }^{77}$ triggered proposals by Representative Joe Moakley (D-Mass.). ${ }^{78}$ The St. Louis ${ }^{79}$ and Kansas City, Missouri ${ }^{80}$ litigation brought Senator Thomas Eagleton into the lists, and the Wilmington struggle $^{81}$ changed the stance of a previously supportive senator, Joseph Biden. ${ }^{82}$ Biden led the 1975 Senate struggle to end the authority of the U.S. Department of Health, Education, and Welfare to require suburban school desegregation through busing ${ }^{83}$ and joined with Eagleton in sponsoring 1977 legislation $^{84}$ even more drastically limiting the Department's powers. ${ }^{85}$

Presidential candidates in 1976 sought some way either to defuse the busing issue or to identify themselves with the antibusing position. President Ford attacked the courts and asked Congress to enact a bill that would strictly limit both the scope and duration of busing orders. ${ }^{86}$ Ronald Reagan campaigned for the GOP convention's platform and endorsed an antibusing amendment to the Constitution. ${ }^{87}$

Yet the issue never became a major theme in any campaign because early efforts to exploit it failed. Even in Boston, which had experienced the country's most severe recent polarization over the issue, Senator Henry Jackson's widely advertised promises to fight "forced busing" were of little avail. Whites for whom this was a "voting issue" were much more likely to vote for an extremist candidate like George Wallace than for a liberal convert to the antibusing wars. ${ }^{88}$ Moreover, Jackson's identification with the issue exposed him

74. See 122 ConG. Rec. S7398 (daily ed. May 18, 1976) (record of urban desegregation prepared by U.S. Dep't of Justice).

75. Milliken v. Bradley, 418 U.S. 717 (1974); Bradley v. Milliken, 484 F.2d 275 (6th Cir. 1973); Bradley v. Milliken, 345 F. Supp. 914 (E.D. Mich. 1972).

76. S. 179, 93rd Cong., 1st Sess. (1973); H.R. 41, 93rd Cong. 1st Sess. (1973).

77. Morgan v. Hennigan, 379 F. Supp. 410 (D. Mass. 1974), aff'd sub nom., Morgan v. Kerrigan, 509 F.2d 580 (1st Cir.), cert. denied, 421 U.S. 963 (1975).

78. H.R. 2392, 94th Cong., lst Sess. (1975).

79. United States v. Missouri, 363 F. Supp. 739 (E.D. Mo. 1973), enforced, 388 F. Supp. 1058 (E.D. Mo. 1975), aff'd in part, rev'd in part and remanded, 515 F.2d 1365 (8th Cir. 1975), modified (E.D. Mo. 1975) (unreported), remanded, 523 F.2d 885 (8th Cir. 1975).

80. School Dist. v. Missouri, 438 F. Supp. 830 (1977), transferred, 460 F. Supp. 421 (1978), appeal dismissed per curiam, 529 F.2d 493 (1979).

81. Evans v. Buchanan, 393 F. Supp. 428 (D. Del.), aff'd mem., 423 U.S. 963 (1975).

82. Wilmington Morning News, June 15, 1974; id., July 10, 1974.

83. S.J.Res. 119 94th Cong., 1st Sess. (1975). Opposition to busing of students (printed) (July $31,1975)$.

84. Eagleton-Biden Amendment of 1977, Pub. L. No. 95-205, 91 Stat. 1460 (1977).

85. N.Y. Times, June 17, 1977, at 1, col. 3.

86. President's Message to Congress Transmitting the Proposed School Desegregation Standards and Assistance Act of 1976, 12 Weekly Comp. of Pres. Doc. 1080 (June 28, 1976).

87. GOP Platform Highlights, Cong. Q. 2296 (Weekly Rep., Aug. 21, 1976).

88. Wash. Post, March 1, 1976, § A, at 4, col. 5. 
to a biting counterattack in the crucial Florida primary where Jimmy Carter accused Jackson of using an issue "which has connotations of racism." ${ }^{89}$

Carter's own position on the issue was carefully crafted to reflect both the unpopularity of the issue and its declining importance. Carter hailed the integration of Southern schools but said that he opposed large-scale busing, and preferred voluntary plans and increased black control over segregated inner city school systems. He promised, however, to enforce the law and oppose efforts to amend the Constitution. The Democratic convention adopted a statement that was only modestly more supportive, calling busing a "judicial tool of last resort."90 The platform called for active work on other approaches, including the use of magnet schools. ${ }^{91}$ President Carter avoided the issue completely during his first year in office. The Justice Department adopted a more positive attitude, but it neither initiated important new cases nor pressed for the cross-district plans needed to accomplish integration in many cities. ${ }^{\mathbf{2}}$

Pronouncements of candidates and government officials do much to set the atmosphere within which desegregation plans are shaped. During the mid-1970s their almost uniform opposition to busing convinced many that busing itself was the problem. The consequence was a strong tendency to propose plans requiring a minimum amount of busing. ${ }^{93}$ It was assumed that minimizing busing would diminish opposition to desegregation and enhance residential stability, although existing research provides no support for these assumptions. ${ }^{94}$

\section{B. The Empirical Assumptions on which Desegregation Policies Are Based}

Explicit or implicit assumptions about society and racial change underlie the various desegregation policies that are put forward. Although policymakers often claim that their assumptions are supported by research, their information about existing research usually is derived through the selective screens of the media and political debate. One can, however, identify the empirical

89. N.Y. Times, March 4, 1976, at 20, col. 1.

90. 122 ConG. Rec. S1 1580 (daily ed., July 2, 1976).

91. Id.

92. The Department did respond to the requests of federal judges in St. Louis and Cleveland that it become a participant in pending litigation, but it did not initiate new urban cases. The Department in the Carter Administration took a more supportive role than the Ford Administration Justice Department officials had in urging city-wide desegregation in the Dayton case. See United States' Amicus Curiae brief No. 76-539, Dayton Bd. of Educ. v. Brinkman, 433 U.S. 406 (1977).

93. In Corpus Christi, Texas, the school district reached the illogical extreme of requiring "massive crosstown walking," assigning 10,000 students to schools up to 1.9 miles outside their neighborhoods, without providing any transportation. Ozio, Corpus Christi, 15 InTEgrated EduC., Nov.-Dec., 1977, at 5.

94. But see Rossell, School Desegregation and Community Social Change, supra note 42 at 133. 
assumptions on which specific policy decisions rest and determine the extent to which they are congruent with or in clear conflict with existing research findings.

The desegregation plans submitted by school districts and the policies promoted by Congress and the executive branch in recent years reflect the following implicit assumptions about the desegregation process:

1. The amount of busing is the principal basis for resistance to desegregation; political controversy will be far less severe with less busing;

2. Large-scale desegregation plans intensify white flight; limited plans produce greater stability;

3. Voluntary procedures (particularly magnet school plans) can produce substantial integration;

4. One-way busing is an acceptable solution;

5. Desegregation plans that exclude the early grades are more effective;

6. Integration of faculties is a significant step even in the absence of student integration;

7. Bilingual education programs meet the principal needs of Hispanic children and are more effective in ethnically isolated schools or classrooms;

8. There are alternatives to integregation-e.g., community controlled schools or compensatory education that may be more effective than desegregation and are more acceptable to minority as well as majority children.

In the last two years, some court-ordered plans have come to reflect the same assumptions, implicitly eroding a series of constitutional requirements that had been articulated in earlier cases. ${ }^{95}$

95. The Supreme Court's declaration in the Little Rock case, Cooper v. Aaron, 358 U.S. 1 (1958), that public resistance could not be allowed to prevent the enforcement of constituttional rights seems to militate against restricting the scope of desegregation in order to lessen the extent of white flight. Restricting the scope of desegregation plans also appears to violate the mandate of Green v. County School Bd., 391 U.S. 430 (1968), that school systems must eliminate racially identifiable schools. Plans accepted by some courts fail to comply with the Supreme Court's unanimous decision in Alexander v. Holmes County Bd. of Educ., 396 U.S. 1218 (1969), that school districts be desegregated immediately once a violation was proven. Swann v. CharlotteMecklenburg Bd. of Educ., 402 U.S. 1 (1971). which upheld systemwide busing where necessary to disestablish a dual school system, and which held that the burden was on the school district to demonstrate that one-race schools were not "vestiges" of past de jure segregation, seems to be ignored. The right of Hispanic children to be educated in a desegregated system, as articulated in Keyes v. School Dist. No. 1, 413 U.S. 189 (1973), is often neglected in the establishment of ethnically isolated bilingual programs. 


\section{The Return to Freedom of Choice: The Magnet School Movement}

In perhaps the most important decision since Brown, the Supreme Court ruled in 1968 that merely offering black students "freedom of choice" to transfer schools was not enough. ${ }^{96}$ To be acceptable, school desegregation plans must actually uproot the system of separate schools. ${ }^{97}$ As a result of this decision, substantial desegregation occurred in the South.

Ironically, a decade later a new variation of the "freedom of choice" plan has become the favored approach to desegregation in cities across the country. The premise of the so-called magnet school plan is that black, Hispanic, and white students can be attracted in sufficiently large numbers to desegregated schools that offer special educational approaches to make compulsory busing unnecessary. Magnet schools have become the centerpiece of school desegregation plans in a number of the nation's largest districts-for example, St. Louis, San Diego, Houston, Cincinnati, Chicago, Milwaukee, and Philadelphia. The magnet school plan is often presented to the community, the press and the courts as an effective method of ending segregation. The fact that no large urban district has ever been fully desegregated through the use of magnet schools is ignored.

It is not surprising that local school authorities proposed the magnet school idea and that local politicians hailed it, since this would mean no involuntary busing of any children. The surprising thing, however, is the increasingly serious way some courts have treated the issue. Congress further heightened interest in this approach to desegregation by enacting a law providing funds for the development of magnet school programs. ${ }^{98}$ Although nothing in the measure limited the right of the courts to order further desegregation, the congressional action did tend to reinforce the notion that magnet schools were a serious alternative solution.

During 1977 virtually all of the large urban school desegregation cases on the West Coast involved magnet school plans. The Pasadena school board included magnet schools in its desegregation plan and appealed to have the compulsory features of the federal court order dropped. The state court judge in the San Diego case accepted a plan that provided that 3,000 of the district's 120,000 children would be enrolled in integrated magnet schools.

96. Green v. County School Bd., 391 U.S. 430 (1968). The Court did not hold that a "freedom of choice" plan might in itself be unconstitutional, but stressed that such plans would not be permitted where alternatives "promis[ed] speedier and more effective conversion to a unitary, nonracial school system" existed. Id. at 439, 440-41.

97. Id. at 437-38.

98. Emergency School Aid Act of 1976, Pub. L. No. 94-482, \& 321(a)-(c), 90 Stat. 2216-17 (codified at 20 U.S.C. \$\$ 1603, 1606, 1619 (1976); 122 Conc. Rec. S5733 (daily ed., April 14, 1976). The bill was introduced by Ohio's Senator John Glenn, who was reacting to the fact that five of the largest districts in his state were facing court orders to desegregate. 
Since some of the magnet schools were already in operation, the plan was to involve only 1,100 additional transfers, less than 1 percent of the district's enrollment. The remainder of the plan provided for the establishment of specialized classes in which students from various schools could participate for a portion of the school day. The district planned to bus a total of 900 additional children later in the school year to learning centers one day a week for integrated classes in music and art. ${ }^{99}$

Judge Louis Welsh, an elected judge who would have to run again for office, accepted the school district's proposals, reserving judgment on whether additional steps would be mandated if the voluntary plan failed. The court order actually required that only four additional magnet schools be established, offering curricula in government and law enforcement, schools teaching foreign languages by the immersion method, and elementary schools emphasizing fundamentals. ${ }^{100}$ School desegregation experts for the state of California ranked the chances for the success of this plan very low, noting that "no city in the nation has met a court order to desegregate its schools by using voluntary programs only."101

Another California state judge, Paul Egly, accepted a magnet school plan for the San Bernardino school system, which has a total enrollment of only 31,000 students. The city proposed to desegregate its fifteen most segregated elementary schools by offering special magnet programs in each part of town. In addition, there were to be two-week interracial visits between white and minority schools. NAACP Attorney Nancy Reardan claimed that although the voluntary programs might succeed in moving some black children out of segregated schools, "no voluntary program in California" had brought white volunteers in sufficient numbers to desegregate a ghetto or barrio school. She also objected to the school district's definition of an integrated school as one with an 80 percent white student body. ${ }^{102}$

Although the Los Angeles School District's desegregation plan, which involved little more than voluntary part-time busing of middle grade intermediate level students, had been rejected as inadequate by the California judge, ${ }^{103}$ a program of magnet schools and voluntary transfers was the only plan in operation in the fall of 1977 , pending the development of a more extensive desegregation plan. Two new magnet schools had a voluntary enrollment of 700 children, desegregating about 0.1 percent of the district's students. The voluntary transfer plan, long the city's only desegregation effort, attracted 18,500 students in 1977 , about 3 percent of the district's students and a large

99. San Diego Union, Aug. 6, 1977.

100. Id.

101. Id., Aug. 25, 1977.

102. L.A. Times, Aug. $8,1977, \S 1$, at 20 , col. 4.

103. Crawford v. Board of Educ., 17 C.3d 280, 551 P.2d 28 (1976). 
increase over the previous year. ${ }^{104} \mathrm{~A}$ more extensive plan to desegregate grades four through eight was implemented in September 1978, after the court rejected a purely voluntary approach.

Seattle is yet another major Western community that decided to rely initially on a voluntary approach. ${ }^{105}$ The 59,000 student system, which had never been under a court order to desegregate, opened classes in the fall of 1977 with approximately 4,000 children being bused to twenty-eight city schools offering a variety of magnet programs, which were not necessarily integrated with the regular classes in a given school. The sole integrated experience of some of the children was in the lunchroom. ${ }^{106}$ The Seattle school board responded to the inadequacies of the approach by implementing a mandatory plan in fall of 1978.

The principal desegregation effort in the Upper Midwest continues to revolve around the magnet school approach. The first two years of the Milwaukee desegregation plan relied almost completely on voluntary transfers by minority children to schools with specialized curricula. ${ }^{107}$ Even before the court order, the district's superintendent of schools had been planning large experiments of this type in the hope of retaining the system's middle class white families. By the fall of 1977, out of a total enrollment of approximately $100,000,14,000$ children, nine-tenths of whom were black, were being bused to magnet schools. ${ }^{108}$

Buffalo, New York-the only major system in the state of New York to come under a federal court order-also relied on magnet schools. Judge John T. Curtin accepted a plan for the establishment of eight new magnet schools in lieu of a more extensive desegregation plan. ${ }^{109}$ The school district had previously closed ten schools and opened one magnet school. ${ }^{110}$

Reliance on magnet schools to desegregate occurred even in districts where the practical obstacles to desegregation were relatively minor. For example, in Chula Vista, California, where the busing of only 250 students was required for desegregation, the district abandoned its agreement to desegregate when the federal government provided only half the $\$ 300,000$ the system had requested. Instead a limited magnet school program was adopted,

104. L.A. Times, Sept. $21,1977, \S 2$, at 1, col. 5 .

105. In December 1977, the Seattle school authorities adopted a mandatory plan, recognizing that a totally voluntary approach would fail. Seattle Times, Dec. 15, 1977, at I; N.Y. Times, Jan. 3 , 1978, at 1, col. 5 .

106. Seattle Post-Intelligencer, Sept. 8, 1977, $\$$ A, at 5, col. 4.

107. Amos v. Board of School Directors, 408 F. Supp. 765 (E.D. Wis.), aff'd sub nom., Armstrong v. Brennan, 539 F.2d 625 (7th Cir. 1976), vacated and remanded, 433 U.S. 672 (1977).

108. Milwaukee J., Aug. 14, 1977, § 2 at 1. col. 1; id., Sept. 6, 1977. Id., Sept. 13, 1977

109. Arthur v. Nyquist, 415 F. Supp. 904 (W.D. N.Y. 1976), aff'd, 429 F. Supp. 206 (W.D.

N.Y. 1977), aff'd in part, rev'd and remanded in part, 573 F.2d 134 (2d Cir. 1978).

110. Buffalo Evening News, Aug. 10, 1977. 
which was designed to reach no more than a third of the students. ${ }^{111}$

Even the largest school systems resorted to magnet school solutions in spite of the fact that the record had been highly disappointing to similar districts in the past. Chicago, which had two magnet schools, responded to heavy pressure from the Illinois State Board of Education with a first stage plan for 1977 that bused 700 children out of overcrowded ghetto schools. The city's planning for future desegregation emphasized five more years of voluntary efforts costing $\$ 50$ million a year. ${ }^{12}$ The Los Angeles plan ${ }^{113}$ remained partially voluntary for the 1978-79 school year, though there was a provision for limited mandatory desegregation in grades four to eight. ${ }^{114}$

The popularity of magnet schools and other voluntary approaches grew even as the research evidence on their failure to achieve desegregation became increasingly unambiguous. Though negative research findings seem to have a powerful impact in eroding support for remedies to segregation, negative evidence has no discernible impact on the belief that there are alternatives to busing.

Perhaps the most important test of magnet schools was in Houston, where the plan called for moving 5,000 students from their neighborhood schools to magnet schools. It fell far short of its goal, however. In 1970, the school system had developed a limited desegregation plan that was also a failure. Schools enrolling almost 18,000 minority children but only 1,700 Anglos had been paired. Under this plan, 6,000 Mexican American children were counted as white. Four years later, the segregated nature of the eleven sets of paired schools had significantly worsened, with only about 3 percent of the total remaining population in the "desegregated" schools being Anglo. ${ }^{115}$ The failure of this pairing plan and the need for further steps led to the development of a very extensive magnet school approach. Thirty-four new programs were implemented in 1975 and another eleven in 1976. When the program began, 3,167 students transferred, but a number of schools involved remained highly segregated. ${ }^{116}$

Although Houston's desegregation plan had left the white population virtually untouched, the city still suffered the rapid decline in Anglo enrollment so characteristic of large cities, falling from 125,000 in 1970 to 83,000 in

111. San Diego Union, Aug. 4, 1977.

112. Chi. Daily News, Sept. 8, 1977, at 1, col. 2; Chi. Trib., Dec. 6, 1977, at 2, col.1

113. Discussed supra notes 103 and 104 and accompanying text.

114. Crawford v. Board of Educ., No. C 822, 854 (Super. Ct. of Cal., Feb. 7, 1978) (unpublished minute order); Los Angeles City Board of Education, 1 Los Angeles Plan for Student Integration: Integrated Educational Excellence Through Choice (Mar. 12, 1979).

115. Campbell \& Brandstetter, The Magnet School Plan in Houston, in The Future of BigCity Schools: Desegregation Policies and Magnet alternatives 124-38 (D. Levine \& $R$. Havighurst eds. 1977).

116. Id. at 137. 
1975. ${ }^{117}$ Critics of course attributed the "flight" of 42,000 students to desegregation, though there had been no busing plan and less than 2,000 white children had ever been involved in involuntary pairing.

The record was similar in St. Louis. There the federal court initially had permitted an out-of-court settlement that attempted to expand integration in the city through voluntary transfers. ${ }^{118}$ Very few schools were desegregated under the plan. ${ }^{119}$ Civil rights groups, with Justice Department support, sued for further action. ${ }^{120}$

Magnet programs in other cities had records ranging from modest positive to negligible consequences. In Cincinnati, which had made an ambitious magnet program the centerpiece of its plan, about one-sixth of the students were enrolled in some kind of alternative school by fall 1975 and the level of segregation in the city was slightly lowered. However, even under the most optimistic projections of local school officials, six-tenths of the students would remain outside the program. ${ }^{121}$ The Chicago school system failed to attract white students to its second highly publicized and highly expensive magnet school. Flint, Michigan-a relatively small system heavily supported by the Mott Foundation-succeeded in transferring two-fifths of its student enrollment to magnet schools programs. Nevertheless, thirteen schools remained as segregated as ever, with more than 90 percent black students. ${ }^{122}$ Most of the magnet schools in Dallas fell far short of their goals, with some remaining "essentially one-race schools." 123

Despite this record, when the long-delayed Philadelphia school desegregation case came to a head in the Pennsylvania state courts the magnet school idea again was relied upon. After nine years of enforcement efforts by the state Human Relations Commission and a favorable state supreme court ruling, ${ }^{124}$ the state trial court held that the school district only need implement its voluntary magnet school plan and granted the district another eighteen months' delay to plan for further desegregation. ${ }^{125}$ The superintendent, how-

117. Id. at 138 .

118. Liddell v. St. Louis Bd. of Educ., 72C-100(1) (E.D. Mo.) (settled Dec. 24, 1975).

119. St. Louis Post-Dispatch, July 6, 1977, § A, at 3, col. 5.

120. The NAACP intervened pursuant to an order by the Court of Appeals for the Eighth Circuit, Dec. 13, 1976, and the Justice Department intervened July 27, 1977. The District Court for the Eastern District of Missouri held that the St. Louis School authorities had met the burden of showing that they had not acted with segregative intent and that all parties were bound by the prior settlement. Liddell v. Board of Educ., 469 F. Supp. 1304 (E.D. Mo., 1979).

121. Waldrip, Alternative Programs in Cincinnati or "What Did You Leam on the River Today?", in The Future of Big-City Schools: Desegregation Policies and Magnet Alternatives 95 (D. Levine \& R. Havighurst eds. 1977).

122. Grant, Flint, 15 InTegrated Educ., Nov.-Dec. 1977, at 18.

123. Trombly, Dallas, 15 Integrated Educ., Nov.-Dec. 1977, at 20.

124. Pennsylvania Human Relations Comm'n v. School Dist., 23 Pa. Cmmw. Ct. 312,352 A.2d 200 (1976).

125. Pennsylvania Hum. Rel. Comm'n v. School Dist., 30 Pa. Commw. Ct. 644, 374 A.2d 1014 (1977), aff'd, 480 Pa. 398, 390 A.2d 1238 (1978). 
ever, announced that the school board probably would not have the necessary money to implement even the voluntary plan, which state officials estimated would integrate no more than 10 to 15 percent of the city's students. ${ }^{126}$

The magnet approach had been chosen in spite of Philadelphia's own prior experience with seven magnet schools. Four of the seven magnet high schools were at least 95 percent black. The only increase in integration had occurred at the magnet school offering aerospace studies where an almost all-white school had attracted about 5 percent more blacks. One magnet school enrolling 3,200 pupils had a total of two white students. ${ }^{127}$

The evidence showed that magnet schools and other "freedom of choice" procedures worked best when they were used not as a substitute for a compulsory plan but as a component of such a plan. When desegregation is inevitable, the development of magnet school curricula can add an important element of educational choice to the process. Boston children, who were required by court order to be bused, ${ }^{128}$ were attracted in large numbers to the special schools developed in the Phase II plan. ${ }^{129}$ Under a clear judicial mandate to implement a compulsory reassignment plan in those schools that could not be desegregated on a voluntary basis, ${ }^{130}$ the Milwaukee school staff developed great interest in encouraging transfers. Without a framework requiring a mandatory change, neither the school administration's interest in making the program work nor the parents' interest in avoiding a forced reassignment is brought into play.

\section{One-Way Desegregation}

Most magnet plans, particularly those in big cities, rely primarily on transfers of minority children to schools in white or transition areas. Even when there is mandatory reassignment, policymakers often try to minimize white fears by closing minority schools and busing their students out to white areas.

This trend was evident in several plans adopted in 1977. The very limited Kansas City, Kansas, plan closed a black school and bused 490 children to other schools. ${ }^{131}$ In Fort Wayne, Indiana, three all-black neighborhood schools were closed, and nearly 700 black children were sent elsewhere. ${ }^{132}$ Virtually all of the thousand involuntary transfers as well as the great majority of voluntary changes in Milwaukee involved minority children. ${ }^{133}$ The Portland,

126. Phil. J.-Herald, July 2, 1977.

127. Franklin, Magnet Schools Fail in Philadelphia, Integrated Educ., Nov.-Dec. 1977, at 95.

128. Morgan v. Hennigan, 379 F. Supp. 410 (D. Mass.), aff'd sub nom., Morgan v. Kerrigan, 509 F.2d 580 (1st Cir. 1974), cert. denied, 421 U.S. 963 (1975).

129. Morgan v. Kerrigan, 401 F. Supp. 216, 246-48 (D. Mass. 1975).

130. Amos v. Board of School Directors, 408 F. Supp. 765 (E.D. Wis.), aff'd sub nom., Armstrong v. Brennan, 539 F.2d 625 (7th Cir. 1976), vacated and remanded, 433 U.S. 672 (1977).

131. Kansas City Times, Aug. 29, 1977, § A, at 4, col. 1.

132. Fort Wayne News-Sentinel, Sept. 7, 1977; Fort Wayne J.-Gazette, Sept. 7, 1977

133. Milwaukee J., Aug. 14, 1977, $\S 2$ at 1 , col. 1. 
Oregon, school superintendent rejected busing for white children but permitted the busing of 2,700 minority children from their neighborhood schools. ${ }^{134}$ Superintendent Blanchard had proposed to avoid resegregation by expanding the number of minority students to be bused. ${ }^{135}$ In Delaware, the State Board of Education proposed to desegregate the entire Wilmington metropolitan area using one-way busing of minority students, but this extreme proposal was rejected by the federal court. ${ }^{136}$

There is no social science evidence to suggest that one-way desegregation is superior, and such plans frequently generate overt opposition in parts of the minority community. There was extensive criticism of such plans by the minority communities in Milwaukee and Portland, for example, and black groups filed a lawsuit in Fort Wayne, Indiana, to stop one-way busing. ${ }^{137}$ Black parents strongly criticized a one-way plan in Joliet, Illinois. ${ }^{138}$ The plans were formulated not in response to evidence about the way to desegregate most effectively but in response to evidence about what the white community would accept. Polls showing whites more ready to accept one-way plans are taken seriously. ${ }^{139}$ Research suggesting that the white fear of violence in schools in black neighborhoods has no basis in fact is ignored. ${ }^{140}$

\section{Desegregating Everything but the Students}

Under intense political pressures against school busing, much of the enforcement energy of the executive branch has focused in recent years on desegregating teachers while student segregation remains untouched. When HEW began compliance reviews of the nation's largest cities in the early seventies, it focused on the equality of school programs, ${ }^{141}$ the distribution of faculty members by race, ${ }^{142}$ and the provision of bilingual education programs for students of limited English-speaking ability. ${ }^{143}$

134. Portland Oregonian, July $3,1977, \S \mathrm{B}$ at 5 , col. 1 .

135. Id., July 27, 1977.

136. Evans v. Buchanan, 435 F. Supp. 832, 840 (D. Del. 1977).

137. Altevogt \& Nusbaumer, Black Parents and Desegregation in Fort Wayne, 16 INTEGRATED EDUC. 31 (July-Aug. 1978).

138. Chi. Tribune, Jan. 25, 1978, § 1, at 3, col. 1 .

139. See, e.g., L. Harris, The Anguish of Change 244-45 (1973); Schwartz \& Schwartz, Convergence and Divergence in Political Orientations between Blacks and Whites: 1960-1973, $32 \mathrm{~J}$. Soc. IssUES, Spring 1976, at 157.

140. See, e.g., Information prepared by Community Relations Service, U.S. Dep't of Justice, in 122 Cong. Rec. Si0708 (daily ed. June 26, 1976); U.S. Comm'n on Civil Rights, Fulfilling the LetTer and Spirit of the Law: Desegregation of the Nation's Schools 145-46 (1976).

141. The lengthy initial HEW outline of the New York City review, for example, did not even mention the segregation issue. G. Orfield, Must We Bus? Segregated Schools and National Policy 300 (1978).

142. In New York, the extensive faculty desegregation plan that resulted produced a political uproar. Less attention was given to negotiation of similar plans in Chicago, Los Angeles, and elsewhere.

143. A federal administrative law judge found Chicago in violation of bilingual education 
After federal district judge John Sirica found HEW guilty of failing to enforce its own Title VI regulations, the agency was forced to initiate fund cut-off proceedings against a number of major school districts based on the violations disclosed in its investigations. ${ }^{144}$ Faced with the prospect of losing federal aid, Chicago, New York City, and other school systems agreed to plans to redistribute their teachers proportionately across all schools. ${ }^{145}$ Many other districts agreed to similar requirements in order to be eligible for Emergency School Aid Act (ESAA) funds. ${ }^{146}$

Faculty desegregation has long been recognized both by the courts ${ }^{147}$ and by many social scientists ${ }^{148}$ as a vital component of successful school desegregation. Without ending faculty segregation, the racial identifiability of schools would remain and students would lack role models of adult integration and the opportunity to relate to adults of their own and other racial and ethnic backgrounds.

There is no theory, however, to suggest that faculty desegregation in itself has significant positive impacts. The identity of a school with virtually all Hispanic students, for instance, is not significantly changed by the arrival of a few Anglo or black teachers. Nor is it clear that there will be any significant impact when a few Hispanic teachers are assigned to work in an all-Englishlanguage school. When student and teacher desegregation occur together, the entire school is fundamentally reconstituted, providing an opportunity to develop a new educational program responding to more diversified needs. Faculty desegregation without student desegregation produces a far more ambiguous transformation, which may sometimes be counterproductive.

\section{4. "Equal Opportunity" Through Segregation}

Another example of policy development without any empirical basis is reflected in HEW's conclusion that the problem of Hispanic children was not one of segregation but of language. Noting the low achievement scores of

requirements on February 15, 1977. Chicago responded by negotiating an extensive agreement to avoid the loss of federal aid.

144. Brown v. Weinberger, 417 F. Supp. 1215 (D. D.C. 1976) (Northern and Western school districts). See also Adams v. Califano, 430 F. Supp. 118 (D. D.C. 1977); Adams v. Weinberger, 430 F. Supp. 118 (D. D.C. 1977); Adams v. Richardson, 356 F. Supp. 92 (D. D.C. 1973) (Southern school districts).

145. Chi. Tribune, Oct. 13, 1977, § 1, at 1, col. 5; N.Y. Times, Oct. 3, 1977, at 27, col. 1.

146. Emergency School Aid Act of 1976, Pub. L. No. 94-482, § 321(a)-(c), 90 Stat. 2216-17 (codified at 20 U.S.C. $\$ \$ 1601-1619$ (Supp. V 1975). The purpose of this act is to provide financial assistance to school districts to help them eliminate minority group segregaton and discrimination among students and faculty in public schools and to aid school children in overcoming the educational disadvantages caused by minority group isolation.

147. Bradley v. School Bd., 382 U.S. 103 (1965).

148. See, e.g., Report of Dr. Thomas Pettigrew to the Superior Court of the State of California for the County of Los Angeles in Crawford v. Board of Education, November 14, 1978, pp. 22-23. Crawford v. Board of Educ., 17 C.3d 280, 551 P.2d 28 (1976). 
Hispanic children, HEW blamed English-language instruction, Englishlanguage tests, and cultural bias in the curriculum. The appropriate remedy was defined as implementation of a bilingual-bicultural school program. Although there appeared to be no evidence that such programs would work and although a large majority of Hispanic children knew sufficient English to function in regular classrooms, HEW halted its investigations into segregated schooling and required school systems to adopt the new educational approach. ${ }^{149}$ Scores of districts complied, often relying on federal bilingual program funds to finance the changes. ${ }^{150} \mathrm{~A}$ recent study has found that these bilingual programs are highly segregated and that project directors seldom transfer children back to English-language classrooms after they have mastered the English language. ${ }^{151}$ The first national evaluation of federal bilingual programs, published in 1977, found no evidence that the programs improved either academic achievement or attitudes toward school. There was even some highly controversial evidence that children enrolled in bilingual programs were less likely to improve their English language skills than children for whom no program was provided. ${ }^{152}$ Though the justification for the displacement of desegregation by bilingual remedies was on the basis of educational needs, the movement proceeded without any initial evidence and grew in spite of continued disappointing research results. The advantage of this approach, however, was that it could be implemented with little visibility or controversy since its impact was almost wholly limited to segregated minority communities.

\section{Other Alternatives to Desegregation}

The intense resistance to desegregation has stimulated a continuing search for some other solution to the problems of discrimination in urban schools. The solutions most frequently discussed in Congress and sometimes considered by the courts include additional resources for education in segregated schools and more positions in school administration for nonwhites. Providing additional resources to ghetto and barrio schools rather than integrating them has been a strong and continuous theme. It is reflected in the largest federal aid-to-education program, Title I of the Elementary and Secondary Education

149. For a full account of the development of HEW enforcement procedures, see G. ORFIELD, supra note 141, ch. 7, 9. See also Roos, Bilingual Education: The Hispanic Response to Unequal Educational Opportunity, 42 LAw \& Contemp. Prob., Autumn 1978, at 111.

150. N. Epstein, Language, Ethnicity, and the Schools: Policy Alternatives for Bilingual-Bicultural Education 2, 14-15 (1977) (Institute for Educational Leadership).

151. American Institutes for Research, Evaluation of the Impact of ESEA Title VII Spanish/English Bilingual Education Program (1977).

152. Id. at $\times x \times-x \times x i$. Both the methodology used by this evaluation and the conclusions drawn have been strongly criticized (see sources cited in Roos, supra note 149, at 111, n.64) and the results must be regarded as very tentative. Nonetheless, there is no convincing evidence for the contrary proposition. 
Act, ${ }^{153}$ which channels funds for compensatory and remedial programs to schools with concentrations of poor children. President Nixon's 1972 legislative proposals offered aid to improve inner city schools as an explicit alternative to desegregation. ${ }^{154}$ Legislative proposals to provide substantial funds to these schools, however, have fared very badly on the floor of Congress. ${ }^{155}$

The emphasis on the compensatory program alternative occurred in spite of research showing generally negative evaluations of their educational impact. ${ }^{156}$ When HEW Secretary Richardson testified in behalf of the Administration's bill in 1972, he indicated that there was evidence that desegregation had a positive effect on achievement greater than or equal to that of compensatory programs, which the Nixon Administration proposed to substitute for desegregation. ${ }^{157}$ The negative evidence on compensatory programs was only brought into the policy debate when President Nixon used such evidence to justify his vetoes of education appropriations and when the Supreme Court sought to justify its decision in Rodriguez refusing to overturn inequitable state school finance systems. ${ }^{158}$ Policymakers insisted that compensatory programs worked when desegregation was threatened, but contended that these programs were useless when redistribution was proposed.

Compensatory education as an alternative to desegregation is implicit in the Supreme Court's second Milliken decision. ${ }^{159}$ Three years earlier, the Court had rejected a metropolitan area desegregation plan as a remedy for the de jure segregated school system of Detroit. ${ }^{160}$ When the case was remanded to the federal district court, a very limited desegregation plan was approved-one confined to the Detroit school district and involving the reas-

153. 20 U.S.C. \$ 241 a (Supp. V 1975).

154. Special Message to the Congress on Equal Educational Opportunities and School Busing, Pub. PAPERS 425-43 (March 17, 1972).

155. Congressional Research Service shows substantial declines, in constant-value dollars, in the amounts appropriated for the major federal compensatory and desegregation programs between the early and mid-seventies. See Senate Comm. on Human Resources, 95th Cong., 1st Sess., Desegregation and the Cities-The Trends and Policy Choices 39 (Comm. Print 1977) (prepared by G. Orfield).

156. See T. Thomas \& S. Pelavin, Patterns in ESEA Title I Reading Achievement (1976), for summaries of much of the earlier research literature on this compensatory program. The first major evidence that additional resources have little impact on achievement was in the 1966 Coleman Report.

157. Equal Educational Opportunities Act of 1972: Hearings before Senate Comm. on Labor and Public Welfare, Subcomm. on Education, 92d Cong., 2d Sess. 289 (1972) (testimony of HEW Sec. Elliot Richardson).

158. San Antonio Independent School Dist. v. Rodriguez, 411 U.S. 1, 23-27 (1973).

159. Milliken v. Bradley, 433 U.S. 267 (1977).

160. Milliken v. Bradley, 418 U.S. 717 (1974). The district court had noted that "relief of segregation in the public schools of the City of Detroit [could] not be accomplished within the corporate geographical limits of the city," since the school population at that time was already three-fourths black. Unreported findings of fact and conclusions of law (E.D. Mich. Mar. 28, 1972), quoted in Bradley v. Milliken, 484 F.2d 215, 244 (6th Cir. 1973). 
signment of only about a tenth of the district's pupils. ${ }^{161}$ The district judge, however, required the state government to finance various programs in remedial reading, counseling and career guidance, multi-ethnic topics, and staff training. ${ }^{162}$ The Supreme Court unanimously sustained this unusual order, ${ }^{163}$ providing the first definitive judicial recognition of what has become increasingly apparent in research on desegregation-that desegregation is a long process requiring curricular and other educational changes to make it effective. ${ }^{164}$ Nevertheless, the practical effect of the Supreme Court's decisions in the Milliken cases, first preventing any significant desegregation by prohibiting a metropolitan area plan, and then providing money for compensatory education programs, may be to push frustrated litigants toward the latter as an alternative to desegregation rather than as a necessary component of desegregation.

In the late sixties, the community control movement, which originated in Harlem and Bedford-Stuyvesant in New York, attracted many who thought that the problems of segregated schools could be solved by turning over the schools to the black or Hispanic community, which would then run the schools with minority administrators and teachers. In Atlanta, a "compromise" was reached in which further efforts toward integration were abandoned in exchange for the allocation of more administrative positions, including that of superintendent, to blacks. ${ }^{165}$ A similar compromise was included in the Dallas plan ${ }^{166}$ and the issue has been raised in other cities.

The community control movement was widely studied. After an initial burst of writing hailing the idea as a way out of the impasse of big city school bureaucracies, studies indicated that the actual effect of community control in New York was serious community conflict with no demonstrable educational gains. ${ }^{167}$ Nor is there much evidence that minority teachers would be more

161. 402 F. Supp. 1096 (E.D. Mich. 1975).

162. Discussed in Milliken II, 433 U.S. at 275, 276 \& 294 n.2 (Powell, J., concurring).

163. See discussion of this decision in Yudof, supra note 55, at notes 214-226 and accompanying text.

164. See, e.g., Orfield, How to Make Desegregation Work: The Adaptation of Schools to Their NewlyIntegrated Student Bodies, 39 Law \& Contemp. Prob., Spring 1975, at 315.

165. Calhoun v. Cook, 362 F. Supp. 1249 (N.D. Ga.), 487 F.2d 680 (5th Cir. 1973). See D. Bell, Waiting on the Promise of Brown, 39 LAw \& Contemp. Prob., Spring 1975, at 341, 358-59.

This plan was negotiated by Griffin Bell, Now Attorney General. It was strongly supported by Andrew Young, and by Jimmy Carter (both as governor of Georgia and during his 1976 presidential campaign). Mashek, What Carter Believes, U.S. News \& WorLd RePT., May 24, 1976 at 18-19, 23.

166. The district court's 1976 plan called for ratios of $44 \%$ Anglo, $44 \%$ black, and $12 \%$ Mexican American in future top administrative appointments. Tasby v. Estes, 412 F. Supp. 1192, 1219 (N.D. Tex. 1976).

167. See, e.g., Levine, Ocean Hill-Brownsville: Schools in Crisis (1969).

Recent elections to select members to the governing boards under the New York legislature's watered down version of a community controlled school system produced very little turnout. Only $8 \%$ of the eligible voters went to the polls in 1977, and the candidates endorsed by the United 
fair to minority children than Anglo teachers. A study of teacher-student interaction in classrooms in the Southwest, for example, found that Mexican American teachers were even more inclined than Anglo teachers to reward Anglo children disproportionately. ${ }^{168}$ Preliminary research has failed to find that programs emphasizing the child's language and culture have any significant impact on children's attitudes toward school or even on their attendance rates. ${ }^{169}$ It is apparent that minority school administrators confront many of the same problems of politics, union relations, urban social and economic collapse, and class conflict between teachers and low income students that afflicted their white predecessors. ${ }^{170}$ Nonetheless, the idea of transferring bureaucratic power to minorities as an alternative to desegregating the students remains very much alive.

\section{$\mathrm{V}$}

\section{Politics, Litigation and White Flight Research}

Despite the fact that research on alternatives to desegregation indicates that they have little educational impact, such research has been ignored, and the alternatives continue to be promoted. At the same time, research that indicates busing increases white flight has been given close attention. Indeed, some school districts have commissioned this kind of research for use in opposing court-ordered busing.

During the Los Angeles school desegregation litigation, the school district commissioned a survey asking parents whether they would remove their children ${ }^{171}$ from city schools if the court were to require a desegregation plan that went beyond the school district's proposed part-time voluntary plan. Since many parents indicated that they would remove their children under such circumstances, the school district tried to introduce this survey as evidence that a mandatory plan would be counterproductive. The St. Louis school district followed the same approach. Governor Jerry Brown illustrated the political value of the issue. He commented that white flight was an inescapable "reality" and used this as reason for attacking the judge in the Los Angeles case:

Federation of Teachers won most of the positions. New York Times, May 18, 1977, \& B, at 5, col. 5. Nonpartisan special elections for school board members, however, usually produce a low voter turnout, particularly in poorer neighborhoods. L. Zeigler \& M. Jennings, Governing American Schools: Political Interaction in Local School Districts (1974).

168. U.S. Comm'n on Civil Rights, Report V: Mexican american Education Study,

Teachers and StUdents (1973).

169. AmERICAN InSTITUtes fOR RESEARCh, supra note $151, \S \mathrm{VI}$, at 27.

170. One dramatic indication of conflict between black administrators and black elected officials was the firing of Barbara Sizemore, the first black woman superintendent, in Washington, D.C., by the majority black school board.

171. Marylander Marketing Research, Results of the L.A.U.S.D. Survey (1977). 
The philosophers and judges can issue their edicts, but we are a free country, and if people don't like what they see in the schools, they just get in the car and go to a private school, move to Ventura, go to Riverside, go to Orange County and that's exactly what's happening. ${ }^{172}$

One major conclusion of the white flight research-that the most stable desegregation plans are not the limited plans but those that are metropolitanwide ${ }^{173}$ - is almost always ignored by policymakers. Although a study of the St. Louis school district came to this conclusion, ${ }^{174}$ the issue of white flight was raised instead as an argument for a more limited plan within the city.

Missouri's Senator Thomas Eagleton defended his 1977 break with civil rights groups on the basis of the negative conclusions of some white flight research, ignoring the metropolitan issue. He justified his bill stripping HEW of authority to require busing in urban areas ${ }^{175}$ because he was convinced that stable desegregation was impossible in cities with less than 50 percent white students. ${ }^{176}$ In Kansas City, he charged, HEW was planning on "sprinkling an ever-dwindling ration of white students among all-black schools." ${ }^{77}$ Local civil rights leaders on the Missouri Advisory Committee to the U.S. Commission on Civil Rights replied that if Eagleton's concern was for stable, majority-white desegregation, he should have supported the Kansas City school board's suit for a metropolitan plan rather than attacking HEW's more limited authority to require busing only within school district boundaries. ${ }^{178}$ Once again, a policy position was justified on the basis of a selective perception of social science evidence, and a politically-inspired interpretation of its policy implications.

\section{VI}

\section{What Should Be Done?}

At a time when consensus on the legal requirements for desegregation and on the desirability of urban school desegregation as a policy have broken down, both better reporting of information on existing research and new research are needed. The best source of information about the effect of school desegregation policies is social science research. Yet a judge or a school official with the best of intentions could not readily untangle the controversies over results of research that now spread across several disciplines, sometimes in-

172. L.A. Times, July 24, 1977, § 1 , at 1 , col. 6 .

173. Coleman, Liberty and Equality in School Desegregation, 6 Soc. PoL'y 9, 13 (1976). See Rossell, supra note 94 , at 133 .

174. H. Schmandt, G. Wendel, \& J. Manns, Government, Politics, and the Public Schools: A Preliminary Study of Three Cities (Sept. 2, 1977) (St. Louis University Center for Urban Programs).

175. Eagleton-Biden Amendment of 1977, Pub. L. No. 95-205, 91 Stat. 1460 (1977).

176. 123 Cong. Rec. S10902 (daily ed., June 28, 1977).

177. St. Louis Post-Dispatch, July 24, 1977, § B, at 2, col. 4.

178. Kansas City Star, Aug. 11, 1977. 
volving highly technical methodological disputes and at other times, simply ad hominum attacks on the motivations of scholars.

The adversary process tends to exacerbate the problem for two important reasons. First, both parties tend to seek not the best but the most predictable witnesses. The primary motivation of the parties is victory, not the discovery of "truth." This means that judges often see a narrow range of witnesses strongly identified with particular policy positions. Such evidence is as likely to deepen confusion as it is to illuminate the choices.

The second problem is financial. Increasingly, school boards are investing substantial sums of money in research designed to support arguments for minimal desegregation. Moreover, they have sufficient funds to make effective use of social science consultants. Civil rights organizations, on the other hand, have never been able to finance such research. And when they can afford consultants, it is usually only to draw up a sketchy "nuts-and-bolts" plan estimating the number of children that would have to be reassigned in order to desegregate the school district.

A more useful approach for a court or other agency dealing with a large city school district would be to create an independent group of experts to respond to questions formulated by the judge or agency. This group could assess the existing research on various issues, initiate short-term research where needed, and report its conclusions. The contending parties should also have access to the data, and the right to question the experts when they submit their report.

This procedure, of course, would not solve all the problems. Where the existing research is inadequate, or where existing findings are unclear or contradictory, all the experts could do is report that there are unresolved questions or that the existing research has nothing of value to say. The independent panel would be useful in pointing out clearly spurious claims or misleading use of data by one or both parties. It could also inform the policymakers of trends and elements of consensus that have emerged from research across the country. The process would not produce a desegregation plan but would give policymakers an opportunity to use social science information more realistically as one element in their decisionmaking. ${ }^{179}$

The contribution that social scientists can make to desegregation policy has been limited in part because of the lack of a national commitment to doing sophisticated research on desegregation during the seventies. Major urban school busing plans have been implemented in the past seven years, yet there

179. Courts could enlist social science experts in improving the process of monitoring compliance with court orders. Well designed survey research of students and teachers, for example, would provide a valuable supplement to school district reports and the observations of monitoring committees. 
is no ongoing national assessment of these plans. Not even the relatively simplistic kinds of data used in the 1966 Coleman Report are now being systematically collected. In order to obtain more useful information from social scientists, research-and more adequately funded research-must be undertaken on general urban trends that will shape the context within which desegregation issues should be considered. Congress should direct HEW to initiate a long-term multidisciplinary assessment of the desegregation process to gain an understanding of the conditions under which desegregation works best.

Those federal agencies that have sponsored research and evaluation studies recently ${ }^{180}$ have done a poor job of disseminating them to the academic community. This research, which contains important evidence of some of the factors that make desegregation succeed or fail at the school level, has not had much impact on policymakers or the academic research community. The first step-federally-sponsored conferences, seminars, and workshops on these and similar studies-would be useful both in expanding ways of thinking about the desegregation process and generating discussion that could help shape priorities for a national assessment of the desegregation process.

The second step is to initiate research on the relationship between the effects of school desegregation and other urban policies. Federal and local housing authorities in several communities have been found guilty of intentionally segregating portions of the housing market. As the courts attempt to remedy both kinds of segregation and as civil rights groups, in order to prove a constitutional violation in a school desegregation case, ${ }^{181}$ use evidence that neighborhoods were intentionally developed in a way that guaranteed segregated schools, research on the interaction between governmental housing and school policies is needed. Such research might also aid in shaping mutually reinforcing remedies for both segregated schools and housing.

If research is to play a more useful role, researchers must recognize that some of the serious wounds of the recent controversies have been selfinflicted. Researchers who find themselves in the unusual and understandably gratifying position of being asked for advice on issues of general social policy often express their general value preference, though it may go far beyond the boundaries of existing research. Policymakers and journalists frequently do not understand the limitations of existing research and press for advice where

180. See, e.g., G. Forehand, M. Ragosta, \& D. Rock, supra note 49. J. Coulson, National Evaluation of the Emergency School Aid Act (ESAA) (System Development Corporation, Santa Monica, 1976). The Coulson study was the first of a series of evaluation studies that studied the effect of desegregation in a sample of schools across the country over time.

181. See Taylor, The Supreme Court and Recent School Desegregation Cases: The Role of Social Science in a Period of Judicial Retirement, 42 Law \& Contemp. ProB., Autumn 1978 at 37. 
no reliable information exists. On receiving information, they seldom sort out the components that rely on research evidence, those that express the researcher's current hypotheses, and those that merely reflect his value preferences as a citizen. Social scientists must operate with full awareness of these problems and make every effort to separate their roles as clearly as possible.

At best, the relationship between academics and policymakers will be difficult. Selective perceptions of research findings and politically inspired misuse of data will continue. Careful, self-conscious handling of a complex set of responsibilities and a variety of audiences is essential to useful participation by social scientists in the policy arena. Judges and other public officials must have a more realistic understanding of the way academic researchers operate and the kinds of advice they are best equipped to provide. Developing a better relationship will require important changes in procedures and expectations. It is, however, the only way substantially to improve the quality of evidence available for making wise decisions about the future of race relations in enormously complex urban settings. 